\title{
Students' Perceptions of the E-Module in Mathematics and Physics Based on Gender Differences
}

\section{Astalini1*, Darmaji2, Dwi Agus Kurniawan ${ }^{3}$, Auliya Ramadhanti ${ }^{4}$}

1,2,3,4 Jambi University, Indonesia

\section{A R T I C L E I N F O}

Article history:

Received June 12, 2021

Revised June 15, 2021

Accepted October 24, 2021

Available online November 25, 2021

\section{Kata Kunci :}

Persepsi, e-Module, Fisika

Matematika, Gender

Keywords:

Perception, e-Module,

Mathematical Physics, Gender

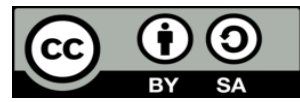

This is an open access article under the $\underline{C C}$ BY-SA license.

Copyright (C) 2021 by Author. Published by Universitas Pendidikan Ganesha

\begin{abstract}
A B S T R A K
Kurangnya kualitas bahan ajar secara otomatis akan mempengaruhi efektifitas dan keberhasilan pembelajaran. Penelitian ini bertujuan untuk menganalisis perbedaan persepsi siswa terhadap produk e-modul Fisika Matematika I materi vektor berdasarkan perbedaan gender. Jenis penelitian ini adalah penelitian kuantitatif dengan teknik analisis statistik deskriptif dan analisis inferensial. Sampel penelitian berjumlah 90 mahasiswa dengan menggunakan simple random. Analisis data dilakukan secara deskriptif dan menggunakan uji normalitas, homogenitas, dan ANOVA dimana signifikansinya lebih dari atau sama dengan 0,05. Hasil uji ANOVA menunjukkan bahwa terdapat perbedaan persepsi. Berdasarkan jenis kelamin dengan nilai signifikansi 0,037 pada wanita dan 0,022 pada pria. Selanjutnya pada post hoc test atau uji lanjut Gabriel menunjukkan bahwa pada kelas $A$ dan $B$ dengan signifikansi 0,047 untuk jenis kelamin perempuan. Sedangkan jenis kelamin laki-laki pada kelas $A$ dan kelas $C$ memiliki perbedaan yang signifikan dengan nilai signifikansi 0,033. Dibandingkan dengan jenis kelamin laki-laki, perempuan memiliki perbedaan yang lebih dominan disebabkan oleh faktor biologis dimana perempuan lebih banyak menggunakan emosinya dibandingkan dengan laki-laki yang pemikirannya lebih realistis. lebih baik. Penggunaan e-modul Matematika Fisika akan sangat membantu siswa dalam proses belajar mengajar agar lebih mudah dipahami dan terkesan menarik. Dengan mengetahui bagaimana perbedaan dan keragaman persepsi siswa terhadap e-modul yang dikembangkan tentunya akan membantu para pendidik dalam membuat bahan ajar yang sesuai dan mampu menarik minat siswa.
\end{abstract}

\begin{abstract}
A B S T R A C T
The lack of quality learning materials will automatically affect the effectiveness and success of learning. This study analyses the differences in students' perceptions of the e-module product Mathematics I vector material based on gender differences. This type of research is quantitative research with descriptive statistical analysis techniques and inferential analysis. The research sample amounted to 90 students using simple random. Data analysis was descriptively carried out using normality, homogeneity, and ANOVA tests where the significance was more than or equal to 0.05 . The results of the ANOVA test showed that there were differences in perception. Based on gender with a significance value of 0.037 in women and 0.022 in men. Furthermore, in the post hoc test or further test Gabriel showed that in class $A$ and $B$ with a significance of 0.047 for the female gender. Meanwhile, the male gender in class $A$ and class $C$ had a significant difference with a significance value of 0.033 . Compared to the male gender, women have more dominant differences caused by biological factors where women use their emotions more than men, whose more realistic thinking is better. The use of the Mathematics e-module will significantly assist students in the teaching and learning process to make it easier to understand and seem interesting. Knowing how the differences and diversity of perceptions of the developed e-modules will certainly help educators make teaching materials that are appropriate and able to attract students' interest.
\end{abstract}

\section{INTRODUCTION}

Technological developments have brought us to a time where information and innovation can be developed very rapidly and unlimitedly. Advances in technology offer various conveniences for humans to obtain information in a short time (Chiroma et al., 2017; Despeisse \& Minshall, 2017; Lopez-Belmonte et al., 2020). The 21st century learning paradigm implies that an educator must use digital technology, appropriate means of communication and/or networks to access, manage, integrate, evaluate and create information to function in learning (Hakak et al., 2019; Khatoon et al., 2021; Leow \& Neo, 2014). Education today should be able to improve a person's ability to be able to adapt to technological advances (Kivunja, 2014; Mortara et al., 2015; Serdyukov, 2017). With the advancement of technology, today's education must be able to adapt it because now there is an innovation called e-learning (Jamun, 2018; Ananda, 2019; Sabri et al, 2021). One of the things that we have to adjust today is the right teaching materials. Teaching materials 
are usually used and of course needed by educators and students. Teaching material is a material / subject matter that is systematically arranged that is used by teachers and students in learning to achieve the expected goals (Kurniawati et al., 2017; Sugiyanto et al., 2019). Teaching materials are materials, information, tools/media used by lecturers to carry out learning including creating an atmosphere that encourages students to learn (Arifin \& Lestari, 2020; Dewi et al., 2018). Lack of quality in teaching materials will automatically affect the effectiveness and success in learning (Fitria \& Idriyeni, 2017; Suzuki et al., 2020). Therefore, educators need teaching materials that are flexible, complete, and include material in a simple manner and in accordance with the technological era, one of the teaching materials that can meet these expectations is with e-modules.

E-module is a module with an electronic format that is run by a computer. E-module is a product of digital-based non-printed teaching materials that can display text, images, animations, and videos through electronic devices such as computers or smartphones (Astalini, Darmaji, et al., 2019; Nisa et al., 2020; Serevina et al., 2018). E-module is also a learning resource that contains materials, methods, limitations and evaluation methods that are systematic and attractive for students designed to achieve competencies that are in accordance with the curriculum electronically (Mazidah et al., 2020; Rahayu \& Sukardi, 2020; Sitorus et al., 2019). According to research from several experts (Astalini et al., 2019; Rahayu \& Sukardi, 2020; Mulyadi et al., 2020). The use of e-modules can increase the effectiveness of student learning in understanding the material. The ability of students to understand the material is of course the main focus in making e-modules, one of which is if the material is difficult and abstract like physics. Physics is a science that can hone students' understanding of a concept. Physics is a branch of science whose object of study consists of the complexity of the relationship between phenomena which ultimately becomes a concept or theory (Astalini, Kurniawan, et al., 2019; Huseby \& Bungum, 2019). Problem solving in physics is very important and fairly difficult and less attractive to students (Manurung \& Panggabean, 2020; Rosidah et al., 2018). Characteristics in studying physics is the science in which the concepts, principles, and laws are studied (Hartini \& Martin, 2020; Shishigu et al., 2018). Physics itself has many branches of science which if studied further will be very beneficial for human life, its application is also very important in future technological developments.

Mathematical physics is a branch of the study of physics that discusses in a structured and systematic way about quantum theory analytically by using mathematical equations (Rohaeti et al., 2019; Serbin et al., 2020). Topics covered are related to advanced courses such as mechanics, modern physics, etc. Which contains an overview of the problem and how to solve it (Saputri, Fadilah, \& Wahyudi, 2016; Cape, 2018; Bustami, Ngadimin, \& Farhan, 2020). Mathematical physics aims to make students have the ability to formulate various physical processes into mathematical statements and be able to solve them analytically, quantitatively, and predictively based on the reasoning model formulated (Gunada et al., 2017; Jonuarti \& Syakbaniah, 2015; FH Nasution, 2017). Many students have difficulty getting satisfactory results, most of them think that the learning media are quite few and also still in foreign languages. By looking at the need for an interactive and communicative media for students, it is necessary to have a product in the form of an electronic module that is integrated with students' perceptions and attitudes towards the course (Pathoni, Jufrida, Saputri, \& Sari, 2017; Jazuli, Azizah, \& Meita, 2018; Darmaji, Astalini, \& Kurniawan, 2019).

Perception is a person's perspective through the process of the five senses to achieve awareness and requires certain items to understand information (Sickle, 2016; Qiong, 2017; Yunita \& Maisarah, 2020). We often find that one's perception of the product is intended to see the quality of the product to be used as a learning resource or not (Darmaji, Astalini, et al., 2019; Hadaya et al., 2018; Serevina et al., 2018; Sofyan et al., 2019). This perception is carried out to find out how students view the mathematics physics e-module I on vector material using Flip PDF Professional software. Flip PDF Professional is an e-book maker software in the form of a flipbook that utilizes various media such as audio, video, and flash (Komikesari et al., 2020; Seruni et al., 2019; Sriwahyuni et al., 2019). This perception will also look at perceptions based on gender differences in each class. Gender itself is a social category that refers to an individual's gender identity, which is divided into women and men (Perry et al., 2019; Sullivan, 2020). In their own perception, gender differences are differences in characteristics, traits, and ways of thinking between men and women (Desiningrum, 2015; Anggoro, 2016; Rizkiyah, Susanto, \& Nugroho, 2016). Women's way of thinking is clearer and their emotions are more visible than men who use their reasoning or are realistic (Hamama et al., 2019; Dilla, Hidayat, \& Rohaeti, 2018; Darsini, Fahrurrozi, \& Cahyono, 2019). Differences in the way of thinking between women and men in the use of e-module media can affect student learning outcomes.

This research was conducted as a complement to previous research about students' perceptions of learning e-modules in the Core Atomic Physics course with the result that students have a good perception of the e-module products made (Pathoni, Jufrida, Saputri, et al., 2017). Then other research, regarding the e-module of the Kinetic Theory of Gas based on 3D Pageflip Professional with the result that students tend to have a good perception of the e-module that is compatible with physics learning materials (Putri et al., 
2020). And the last one is in the research about the development of e-module-based Basic Physics I teaching materials with the result that the products developed are suitable for use so that students are able to study independently (Ramadan et al., 2020). Based on several studies that have been presented above, no research has been found related to the study of student perceptions of e-modules in the Mathematics Physics course, and there is no perception assessment by considering gender differences among students. This is because the difference in human sex is important to be involved in the comparison of the two perceptions of the object to be perceived (Çera et al., 2018; Gazzola et al., 2020; nal et al., 2018). Therefore, to complement the shortcomings of previous research, the researcher wishes to conduct research by examining student perceptions of the Mathematics Physics e-module by considering the differences in student gender. Given the importance of knowing students' perceptions of e-modules, the researchers conducted this study which aims to examine the differences in student perceptions of Regular A, B, and C classes on the Mathematics Physics e-module on vector material based on student gender differences.

\section{METHODS}

This study uses a quantitative research approach. Quantitative research focuses on objectivity and is especially suitable when it is possible to collect measures of variables and measurable conclusions from a sample of a population (Antwi \& Hamza, 2015; Fugard \& Potts, 2015; Mohajan, 2018; Queiros et al., 2017). Quantitative methods are commonly used to analyze data such as questionnaires (Alshenqeeti, 2014; Apuke, 2017; Choy, 2014). Quantitative research is conducted to investigate causal hypotheses that can be manipulated by comparing one or more groups with one comparison group (Appelbaum et al., 2018; Korstjens \& Moser, 2017). This study aims to see the differences in students' perceptions of e-modules in class A, B and C, and also aims to see the differences in students' perceptions of e-modules based on gender in classes A, B and C. The population in this study were students of physics education class of $2019 \mathrm{Jambi}$ University. The whole of all the facts studied is called the population (Asiamah, Mensah, \& Oteng-Abayie, 2017; Nasution, 2017; Jaya, 2019). The sample used in this study were all students of physics education with a total of 90 people consisting of 30 people for class A, 30 people for class B and 30 people for class C. In sampling there are many types of methods that can be used. A sample including individuals from the target group who have had unexplained experiences can also increase the power of information (Gronholm et al., 2017; Malterud et al., 2015; Soto \& John, 2017). The sample used in this study was obtained using a simple random sampling technique. Simple random sampling is the simplest and most commonly used method where every member of the population has an equal chance of being selected as a subject and producing optimal data (Etikan \& Bala, 2017; Pal et al., 2018; Sharma, 2017).

The data in this study were obtained from quantitative data using a questionnaire. Data collection is done by distributing questionnaires or questionnaires via Google Form to students and then filling in the statements that have been given. Questionnaires are a useful method for easily collecting data from participants in a study using a rating scale (Cagetti et al., 2020; Maharani et al., 2020; Owusu-Fordjour et al., 2020; Woerkom et al., 2016). The questionnaire used in this study was made using a Likert scale. Likert scale which is a scale to measure perceptions related to statements that focus on a person's attitude towards something (Joshi et al., 2015; Willits et al., 2016; Wu \& Leung, 2017). The grid of data collection instruments used in this study can be seen in Table 1 .

Table 1. Grid of Student Perception Questionnaire Instruments

\begin{tabular}{ll}
\hline \multicolumn{1}{c}{ Rating Indicator } & \multicolumn{1}{c}{ Rated aspect } \\
\hline E-Module Display & Text clarity \\
& Multimedia size fit \\
& Clarity of color and shape \\
& Multimedia display quality is good \\
& The multimedia presented is interesting \\
Presentation of Material in E-Modules & Easy to understand material \\
& The order of the material is clear \\
& The sentences used are simple and easy to understand \\
& The language used is communicative \\
& The suitability of the example with the material \\
& Multimedia compatibility with the material \\
& Ease of use of the module \\
& Media can help students understand the material \\
Benefits of E-Modules & Interest in using mod mod \\
& Increased learning motivation \\
\hline
\end{tabular}


Research questionnaires given to students have different scores, namely Very Good (SB) = 4 , Good (B) $=3$, Not Good $(\mathrm{TB})=2$, and Very Not Good $(\mathrm{STB})=1$. The data analysis technique in this study used descriptive statistical analysis and inferential analysis. Descriptive statistical analysis was carried out by statistical calculations which included mean, median, mode, maximum value, minimum value and standard deviation. Analytical statistical analysis was carried out using a different test, namely the ANOVA test. ANOVA test is used if the data is normally distributed and homogeneous. Homogeneity test is to find out whether the variance of the data population is the same or not. After the homogeneity test has been fulfilled and the data is known to be normal, the researcher can then perform a direct ANOVA test without having to test the linearity assumption. ANOVA test is a form of hypothesis testing to draw conclusions based on data where the hypothesis $\mathrm{H} 0$ has the same variance and has mean expectations.

\section{RESULT AND DISCUSSION}

\section{Results}

The data obtained from students in three different classes, namely regular a, regular $b$, and regular were analyzed using descriptive statistics based on gender. Based on the results of data analysis, regular class A has a good level of perception of the developed e-module. From the table it can also be seen that as many as 9 girls have a very good level of perception and 8 others have a good level of perception of the Mathematics Physics e-module. Meanwhile, for boys, 7 students have very good perception levels and the remaining 6 students have good perceptions of the Vector Material Mathematics Physics e-module. The regular class $B$ has a good level of perception of the developed e-module. The table also shows that as many as 16 girls (80\%) have a very good level of perception and 4 people (20\%) have a good level of perception of the Mathematics Physics e-module. As for boys, 3 people (30\%) have very good perception levels and 7 people (70\%) have good perceptions of the Vector Material Mathematics Physics e-module. The regular class $\mathrm{C}$ has a good level of perception of the developed e-module. From the table it can be seen that as many as 8 girls (50\%) have a very good level of perception and 8 people (50\%) have a good level of perception of the Mathematics Physics e-module. As for boys, 10 people (71.42\%) had a very good perception level, 4 people (28.57\%) had a good level of perception of the Vector Material Mathematics Physics e-module. After the data were analyzed descriptively, the data was then tested for prerequisites, namely the normality test and homogeneity test. The normality test aims to see the normality of the data. From the normality test data for the three classes above, a significance value is greater than 0.05 . For girls, the significance of regular classes a, b and c was $0.198,0.143$ and 0.200 , while for girls the significance was $0.050,0.095$, and 0.077 respectively. This significance value has met the requirements, which is above 0.05 , which means that the data obtained are normally distributed.

Furthermore, the homogeneity test or the test used to see the homogeneity of the data. From the homogeneity test data for the three classes above, a significance value greater than 0.05 was obtained. For girls, the significance of regular classes $a, b$ and c was $0.101,0.741$ and 0.621 , while for girls the significance was $0.313,0.253$, and 0.526 , respectively. This significance value has met the requirements, namely above 0.05 , which means that the data obtained is homogeneous. After completing the prerequisite test, the researcher then tested the hypothesis using the ANOVA test. The results of the ANOVA test output perceptions of regular class students $a, b$, and c, the significance value is less than 0.05 , which means the data is significantly different. For girls, the significance was 0.039 and for boys it was 0.013 . This value smaller than 0.05 indicates that the perception data of both girls and boys are different from each other. After the ANOVA test was carried out to see whether or not there were differences in the class, it could also be seen which class had different perceptions by means of an advanced test or post hoc test. The post hoc test is a further test after it is known that there are differences in the ANOVA test. Based on data analysis, shows that almost all classes have significant differences in the female gender. But those who qualify with sig > 0.05 are class A and class B with a significance of 0.047 while for other classes there is no significant difference. So it can be concluded that classes A and B have very significant differences in the female gender. Meanwhile, when viewed from the male gender, only classes $\mathrm{A}$ and $\mathrm{C}$ have a significant difference with a significance value of 0.33 . This means that there is a significant difference in classes A and $\mathrm{C}$, while other classes do not.

\section{Discussion}

Perception is how someone perceives something consciously. In this study, researchers will see how the perceptions of students in grades $\mathrm{A}, \mathrm{B}$ and $\mathrm{C}$ are, and how the differences in perceptions of the two classes are if they are grouped again by gender. The data from the perception itself was obtained from a questionnaire that had been distributed to active students of physics education at Jambi University batch 2019 via Google Form. 
In this study, the researcher added a gender variable as a separation of student perceptions. In some studies gender is also a factor that affects one's perception, girls tend to follow the majority of classes and are more competitive in choosing something while boys are more likely to prioritize personal concepts (Çera et al., 2018; Ogungbamila \& Bola Udegbe, 2014; Samuelsson \& Samuelsson, 2016; Rizkiyah, Susanto, \& Nugroho, 2016). In their own perception, gender differences are differences in characteristics, traits, and ways of thinking between men and women (Desiningrum, 2015; Anggoro, 2016; Rizkiyah, Susanto, \& Nugroho, 2016).

We can see in class A of 30 students 9 female students (52.94\%) have very good perceptions and 8 other female students ( $47.05 \%)$ has a good perception. For male students themselves in class A, 7 students $(53.84 \%)$ had a very good perception, and the remaining 6 students $(46.15 \%)$ had a good perception. Then in class B there are still 30 students for female students, almost entirely with 16 students (80\%) having very good perceptions with the remaining 4 students $(20 \%)$ having very good perceptions. As for the male students themselves, about 3 students (30\%) had very good perceptions and the remaining 7 students $(70 \%)$ had good perceptions. The last one in class $\mathrm{C}$ with the same number of students is 30 students, many of which are female students who have very good and good perceptions, the total is the same, namely 8 students each (50\%). For male students themselves, there were 10 students $(71.42 \%)$ who had very good perceptions, and 4 other students (28.57\%) had good perceptions.

After finishing describing the data by statistical analysis, the researcher continued to analyze the data by inderentiality. Before testing the previous hypothesis, the researcher must do a prerequisite test. Prerequisite test is carried out using normality test and homogeneity test (Nurvianti \& Syarkowi, 2018; Kurniawan et al., 2019; Suprianto et al., 2019). Normality test is carried out to test whether a series of observations comes from some fully defined continuous distribution or the data is normally distributed (Das \& Imon, 2016; Filion, 2015; Kwak \& Park, 2019; Lilliefors, 2017). To test for normality, it can be done using the Kolmogorov-Smirnov condition that if the significance value is $>0.05$ then the data can be said to be normally distributed. Homogeneity test was conducted to see whether the data was homogeneous or not, if the value of Sig. greater than $=0.05$, then it shows that H0 is acceptable so it can be concluded that the data variance is homogeneous (Fuad et al., 2017; Laurens et al., 2018; Tekedere \& Göker, 2016). Based on the results of table 6, the significance value for male students is 0.198 (Regular A class 2019), 0.143 (Regular class B), and 0.200 (Regular C class), then for female students it is 0.050 (Regular A class), 0.095 (Regular class A). Regular B), and 0.77 (Regular C class) these results have met the requirements, which are greater than 0.05 so that the data obtained can be said to be normally distributed. Then the researchers conducted the next test, namely the homogeneous test, based on the results of table 7, the significance value for male students was 0.101 (Regular A class 2019), 0.741 (Regular class B), and 0.621 (Regular C class), then for female students it was 0.313 (Regular class A), 0.253 (Regular class B), and 0 .

After the prerequisite test was met, the researcher continued by conducting the ANOVA test and the post hoc follow-up test to see more detailed differences between the three classes in the perception data. It is obtained a significance value of 0.039 for the perception of female female students and 0.013 for male students, in this ANOVA test the data is said to have an average difference if the test results are smaller than 0.05 in the results we get indicating an average difference in each gender. From the previous explanation, gender differences have a great influence on a person's perception, with the factors described that influence the differences in perceptions, especially the different mindsets and perspectives between the two. So there needs to be a deeper analysis so that it can be a correction in the products in the form of e-modules that we offer. Based on data analysis, that almost all classes have significant differences in the female gender. But those who qualify with sig $>0.05$ are class A and class B with a significance of 0.047 while for other classes there is no significant difference. So it can be concluded that classes A and B have very significant differences in the female gender. Meanwhile, when viewed from the male gender, only classes $A$ and $C$ have a significant difference with a significance value of 0.33 . This means that there is a significant difference in classes $\mathrm{A}$ and $\mathrm{C}$, while other classes do not.

The module, which was originally a print learning media, was transformed into an electronic form, giving birth to a new term, namely electronic module or what is known as e-module. (From \& Nasih, 2019; Solikin, 2018; Winatha et al., 2018). This happened as technology developed where everything began to shift from print to online form, or in electronic form. At the university level, things like this are no longer used by some educators as a companion to the main teaching materials that are more concise and easy to understand. With a good e-module assessment, it is hoped that in the future this e-module will help students understand Mathematics Physics learning (Pathoni, Jufrida, Saputri, \& Sari, 2017; Jazuli, Azizah, \& Meita, 2018; Darmaji, Astalini, \& Kurniawan, 2019). In addition, products that use Indonesian and make it simpler and easier to understand are expected to make students free in interpreting learning without worrying about misunderstandings in delivering or discussing material. In the long term, this e-module is believed to 
be able to improve the pedagogic abilities of Physics education students as future teacher candidates who are certainly required to have critical analytical and calculation skills.

Pedagogic ability is a person's ability to teach which includes various aspects related to educating science, basic teaching skills and classroom management so that learning activities can run effectively to achieve educational goals. (Alekhina et al., 2020; Indriani, 2016; Todd, 2014). To be able to improve pedagogic abilities, good and flexible learning media are needed, one of which is utilizing technological advances, namely in this study the e-module of Mathematics Physics I vector material. For educators themselves, perception research like this is very useful in improving the quality of an educator in mastering the material and sharing knowledge with the students he teaches so that they can become professional educators. (Mashuri, 2017; Widyastuti, Widiyaningrum, \& Lisdiana, 2017; Lewis \& Holloway, 2019). By getting good perceptions from students of the e-module product being tested, it can be said that this research also helps educators, especially lecturers in Mathematics Physics I, in seeing what kind of learning students like. This means that if students already like learning, good learning outcomes will follow. Then from the side of the Mathematics Physics course itself,e-modules that get good perception results will certainly help lecturers add complementary learning resources that are easy to understand and simple. So it is hoped that further research may be able to examine how students' perceptions are associated with high-level student thinking skills or student attitudes in studying Mathematical Physics using technological advances, namely e-modules, so that it will produce great benefits for students.

In previous research by experts, The student perception variable was used to increase the effectiveness of learning in the classroom and did not examine the relationship between the perceptions of first graders and other classes (Asrial et al., 2020; Darmaji, Kurniawan, et al., 2019; Serevina et al., 2018). As for other research have differences in the teaching materials used as the contents of the e-module, namely in this study using learning materials in the Core Physics course (Pathoni et all., 2017). Further research using teaching materials in the e-module is gas kinetic theory material using 3D Pageflip Professional (Putri et al., 2020). The last is the research on perception itself only looks at the perceptions of material and media experts without considering students' perspectives by reviewing gender differences (Ramadan et al., 2020). Previous research also only focused on students' perceptions of one class, while the research that the researcher did used more data. However, the research conducted has a weakness where the researcher does not explain specifically the product that is the object of student perception. In addition, the data processed is only limited to measuring the relationship between students' perceptions in the three classes and does not use other variables. Therefore, the researcher suggests that further research is expected to add variables such as students' higher-order thinking skills or students' attitudes towards the developed e-module so that it does not only measure the relationship but the influence between variables.

The use of the Mathematics Physics e-module will greatly help students in the teaching and learning process to be easier to understand and seem interesting. By knowing how different and diverse student perceptions of the developed e-modules are, it will certainly help educators in making teaching materials that are suitable and able to attract students' interest. With a good response to the Mathematics Physics emodule product, it can certainly help students in independent learning and of course make it easier for students to understand various concepts and solve physics problems mathematically so that it will improve the quality of student learning outcomes and in the future will be able to apply their knowledge well as future educators. This study has limitations because this study only discusses students' perceptions of the Mathematics Physics E-Module in terms of gender and does not yet know whether the Mathematics Physics E-Module will impact learning outcomes. The results of this study are expected to provide benefits for educators to identify students' perceptions of e-modules or learning media used to improve the quality of learning at a university and the elementary, junior high, and high school levels. The results of this study can be used as a source and reference for further research by providing innovations so that they positively impact the progress of the teaching and learning process in educational institutions.

\section{CONCLUSION}

A person's perception can be influenced by several factors, one of which is gender. Gender itself dramatically influences the way decisions are made and affects a person's perspective. Based on research, there are differences between the sexes of men and women. Women express their opinions and perceptions of products in the form of e-modules on Vector Physics Mathematics. It is influenced by the way men think, which tends to be logical and conceptualized. The gender differences that are reviewed affect students' perceptions of the Vector e-module for Mathematics and Physics Materials. 


\section{REFERENCES}

Alekhina, E. V., Zolkin, A. L., Parkhomenko, R. N., Pirogov, A. I., Safonov, A. L., Zapalatskaya, V. S., \& Krasnoshlikova, O. G. (2020). Philosophical and pedagogical aspects of career guidance policy for learners and students. Journal of Environmental Treatment Techniques, 8(1), 175-181.

Alshenqeeti, H. (2014). Interviewing as a Data Collection Method: A Critical Review. English Linguistics Research, 3(1), 39-45. https://doi.org/10.5430/elr.v3n1p39.

Anggoro, B. S. (2016). Analisis Persepsi Siswa SMP terhadap Pembelajaran Matematika ditinjau dari Perbedaan Gender dan Disposisi Berpikir Kreatif Matematis. Al-Jabar: Jurnal Pendidikan Matematika, 7(2), 153-166. https://doi.org/10.24042/ajpm.v7i2.30.

Antwi, S. K., \& Hamza, K. (2015). Qualitative and Quantitative Research Paradigms in Business Research : A Philosophical Reflection. European Journal of Business and Management, 7(3), 217-226. https://doi.org/10.1037/amp0000191.

Appelbaum, M., Cooper, H., Kline, R. B., Mayo-wilson, E., Nezu, A. M., \& Rao, S. M. (2018). The APA Publications and Communications Board Task Force Report. Journal Article Reporting Standards for Quantitative Research in Psychology, 73(1), 3-25. https://doi.org/10.1037/amp0000389.

Apuke, O. D. (2017). Arabian Journal of Business and Management Review ( Kuwait Chapter ). Arabian Journal of Business and Management Review (Kuwait Chapter), 6(10), 40-47. https://doi.org/10.12816/0040336.

Arifin, A. syamsul, \& Lestari, E. S. (2020). Genetics bacterial teaching materials development based on flipbook in microbiology subject to improve learning motivation. JPBIO (Jurnal Pendidikan Biologi), 5(2), 202-211. https://doi.org/10.31932/jpbio.v5i2.862.

Asiamah, N., Mensah, H. K., \& Oteng-Abayie, E. F. (2017). General, target, and accessible population: Demystifying the concepts for effective sampling. Qualitative Report, 22(6), 1607-1621. https://doi.org/10.46743/2160-3715/2017.2674.

Asrial, Syahrial, Maison, Kurniawan, D. A., \& Piyana, S. O. (2020). Ethnoconstructivism E-Module to Improve Perception, Interest, and Motivation of Students in Class V Elementary School. JPI Uurnal Pendidikan Indonesia), 9(1), 30-41. https://doi.org/10.23887/jpi-undiksha.v9i1.19222.

Astalini, Darmaji, Kurniawan, W., Anwar, K., \& Kurniawan, D. A. (2019). Effectiveness of Using E-Module and E-Assessment. IJIM, 13(9), 21-39. https://doi.org/10.3991/ijim.v13i09.11016.

Astalini, Kurniawan, D. A., Darmaji, Sholihah, L. R., \& Perdana, R. (2019). Characteristics of students' attitude to Physics in Muaro Jambi High School. Humanities and Social Sciences Reviews, 7(2), 91-99. https://doi.org/10.18510/hssr.2019.7210.

Bustami, Ngadimin, \& Farhan, A. (2020). The Difficulty Factors of Students to Understand Mathematics Physics 1 at Physics Education Department FKIP Unsyiah. Asian Journal of Science Education, 2(1), 1-10. https://doi.org/10.24815/ajse.v2i1.14725.

Cagetti, M. G., Cairoli, J. L., Senna, A., \& Campus, G. (2020). COVID-19 Outbreak in North Italy : An Overview on Dentistry . A Questionnaire Survey. International Journal of Environmental Research and Public Health, 17, 1-12. https://doi.org/10.3390/ijerph17113835.

Çera, G., Cepel, M., Zakutna, S., \& Rozsa, Z. (2018). Gender differences in perception of the university education quality as applied to entrepreneurial intention. Journal of International Studies, 11(3), 147-160. https://doi.org/10.14254/2071-8330.2018/11-3/13.

Chiroma, H., Mohd Shuib, N. L., Abubakar, A. I., Zeki, A. M., Gital, A. Y. U., Herawan, T., \& Abawajy, J. H. (2017). Advances in Teaching and Learning on Facebook in Higher Institutions. IEEE Access, 5, 480-500. https://doi.org/10.1109/ACCESS.2016.2643682.

Choy, L. T. (2014). The Strengths and Weaknesses of Research Methodology: Comparison and Complimentary between Qualitative and Quantitative Approaches. IOSR Journal Of Humanities And Social Science, 19(4), 99-104. https://doi.org/10.9790/0837-194399104.

Dari, R. W., \& Nasih, N. R. (2019). Identifikasi Tingkat KPS Mahasiswa Praktikum Pembiasan Kaca Plan Paralel Menggunakan Panduan Praktikum Berbasis E-Modul. JIFP Jurnal Fisika Dan Pembelajarannya), 3(2), 47-57.

Darmaji, Astalini, \& Kurniawan, D. A. (2019). E-Module Based Problem Solving in Basic Physics Practicum for Science Process Skills. IJOE, 15(15), 4-17. https://doi.org/10.3991/ijoe.v15i15.10942.

Darmaji, D., Kurniawan, D. A., \& Suryani, A. (2019). Effectiveness of Basic Physics II Practicum Guidelines Based On Science Process Skills. JIPF (Jurnal Ilmu Pendidikan Fisika), 4(1), 1. https://doi.org/10.26737/jipf.v4i1.693.

Das, K. R., \& Imon, A. H. M. R. (2016). A Brief Review of Tests for Normality. American Journal of Theoretical and Applied Statistics, 5(1), 5-12. https://doi.org/10.11648/j.ajtas.20160501.12.

Desiningrum, D. R. (2015). Kesejahteraan Psikologis Lansia Janda/Duda Ditinjau dari Persepsi Terhadap Dukungan Sosial dan Gender. Jurnal Psikologi Undip, 13(2), 102-106. 
https://doi.org/10.14710/jpu.13.2.102-201.

Despeisse, M., \& Minshall, T. (2017). Skills and education for additive manufacturing: A review of emerging issues. IFIP Advances in Information and Communication Technology, 513, 289-297. https://doi.org/10.1007/978-3-319-66923-6_34.

Dewi, N. R., Kannapiran, S., \& Wibowo, S. W. A. (2018). Development of digital storytelling-based science teaching materials to improve students' metacognitive ability. Jurnal Pendidikan IPA Indonesia, 7(1), 16-24. https://doi.org/10.15294/jpii.v7i1.12718.

Etikan, I., \& Bala, K. (2017). Sampling and sampling methods. Biometrics \& Biostatistics International Journal, 5(6), 215-217. https://doi.org/10.15406/bbij.2017.05.00149.

Filion, G. J. (2015). The signed Kolmogorov-Smirnov test : why it should not be used. GigaScience, 4(9), 7-9. https://doi.org/10.1186/s13742-015-0048-7.

Fitria, Y., \& Idriyeni, I. (2017). Development of Problem-Based Teaching Materials for The Fifth Graders of Primary School. Jurnal Ta'dib, 20(2), 99-106. https://doi.org/10.31958/jt.v20i2.747.

Fuad, N. M., Zubaidah, S., Mahanal, S., \& Suarsini, E. (2017). Improving Junior High Schools ' Critical Thinking Skills Based on Test Three Different Models of Learning. International Journal of Instruction, 10(1), 101-116. https://doi.org/10.12973/iji.2017.1017a.

Fugard, A. J. B., \& Potts, H. W. W. (2015). Supporting thinking on sample sizes for thematic analyses : a quantitative tool. International Journal of Social Research Methodology, 18(6), 667-681. https://doi.org/10.1080/13645579.2015.1005453.

Gazzola, P., Pavione, E., Pezzetti, R., \& Grechi, D. (2020). Trends in the fashion industry. The perception of sustainability and circular economy: A gender/generation quantitative approach. Sustainability (Switzerland), 12(7), 1-19. https://doi.org/10.3390/su12072809.

Gronholm, P. C., Henderson, C., Deb, T., \& Thornicroft, G. (2017). Interventions to reduce discrimination and stigma: the state of the art. Social Psychiatry and Psychiatric Epidemiology, 52(3), 249-258. https://doi.org/10.1007/s00127-017-1341-9.

Gunada, I. W., Rokhmat, J., Hikmawati, H., \& Kesipudin, K. (2017). Pengembangan Bahan Ajar Kompilasi Fisika Matematika Ii Pokok Bahasan Persamaaan Diferensial Untuk Meningkatkan Penalaran Matematis. Jurnal Pendidikan Fisika Dan Teknologi, 3(2), 216. https://doi.org/10.29303/jpft.v3i2.414.

Hadaya, A., Asrowi, \& Sunardi. (2018). Perception of Junior High School Students about the Use of E-books as Learning Sources. Jurnal of Educational Science and Technology, 4(1), 55-61. https://doi.org/10.26858/est.v4i1.5219.

Hakak, S., Noor, N. F. M., Ayub, M. N., Affal, H., Hussin, N., ahmed, E., \& Imran, M. (2019). Cloud-assisted gamification for education and learning - Recent advances and challenges. Computers and Electrical Engineering, 74, 22-34. https://doi.org/10.1016/j.compeleceng.2019.01.002.

Hamama, S. F., Hallaby, S. F., \& Ramona, S. (2019). Analisis Persepsi Siswa Berdasarkan Gender Terhadap Pembelajaran Biologi di Dalam Kelas. Jurnal Dedikasi Pendidikan, 8848(1), 21-26.

Hartini, T. I., \& Martin, M. (2020). Pengaruh Penggunaan Model Pembelajaran Problem Solving Sistematis terhadap Hasil Belajar Fisika Dasar 2 Materi Listrik Arus Searah pada Mahasiswa Pendidikan Fisika. Silampari Jurnal Pendidikan Ilmu Fisika, 2(2), 163-174. https://doi.org/10.31540/sjpif.v2i2.1101.

Huseby, A., \& Bungum, B. (2019). Observation in quantum physics: Challenges for upper secondary physics students in discussing electrons as waves. Physics Education, 54(6). https://doi.org/10.1088/13616552/ab3694.

Indriani, F. (2016). Kompetensi Pedagogik Mahasiswa dalam Mengelola Pembelajaran Tematik Integratif Kurikulum 2013 pada Pengajaran Micro Di PGSD UAD Yogyakarta. Journal of Elementary School, 3(1), 1-12. https://doi.org/10.1002/j.0022-0337.2015.79.12.tb06048.x.

Jaya, I. (2019). Penerapan Statistik untuk Penelitian Pendidikan (pertama). Prenadamedia Group.

Jazuli, M., Azizah, L. F., \& Meita, N. M. (2018). Pengembangan Bahan Ajar Elektronik Berbasis Android Sebagai Media Interaktif. LENSA (Lentera Sains): Jurnal Pendidikan IPA, 7(2), 47-65. https://doi.org/10.24929/lensa.v7i2.22.

Jonuarti, R., \& Syakbaniah. (2015). Identifikasi Kesulitan Mahasiswa Dalam Menyelesaikan Soal Fisika Matematika I Di Jurusan Fisika Universitas Negeri Padang. Jurnal Eksakta, 1(16), 82-87.

Joshi, A., Kale, S., Chandel, S., \& Pal, D. K. (2015). Likert Scale : Explored and Explained. British Journal of Applied Science \& Technology, 7(4), 396-403. https://doi.org/10.9734/BJAST/2015/14975.

Khatoon, B., Hill, K., \& Walmsey, A. (2021). Instant Messaging in Dental Education. Journal of Dental Education, 79(12), 1471-1478. https://doi.org/10.1002/j.0022-0337.2015.79.12.tb06048.x.

Kivunja, C. (2014). Do You Want Your Students to Be Job-Ready with 21st Century Skills? Change Pedagogies: A Pedagogical Paradigm Shift from Vygotskyian Social Constructivism to Critical Thinking, Problem Solving and Siemens' Digital Connectivism. International Journal of Higher 
Education, 3(3), 81-91. https://doi.org/10.5430/ijhe.v3n3p81.

Komikesari, H., Mutoharoh, M., Dewi, P., Utami, G., Anggraini, W., \& Himmah, E. (2020). Development of emodule using flip pdf professional on temperature and heat material Development of e-module using flip pdf professional on temperature and heat material. Journal Of Physics Conference Series. https://doi.org/10.1088/1742-6596/1572/1/012017.

Korstjens, I., \& Moser, A. (2017). Series: Practical guidance to qualitative research . Part 2 : Context , research questions and designs. European Journal of General Practice, 23(1), 274-279. https://doi.org/10.1080/13814788.2017.1375090.

Kurniawan, W., Darmaji, D., Astalini, A., Kurniawan, D. A., \& Hidayat, M. (2019). Multimedia physics practicum reflective material based on problem solving for science process skills. International Journal of Evaluation and Research in Education (IJERE), 8(4), 590-595. https://doi.org/10.11591/ijere.v8i4.20258.

Kurniawati, M. W., Anitah, S., \& Suharno, S. (2017). Developing Learning Science Teaching Materials Based on Scientific to Improve Student Learning Outcome in Elementary School. European Journal of Education Studies, 20, 319-330. https://doi.org/10.5281/zenodo.398991.

Kwak, S. G., \& Park, S. (2019). Normality Test in Clinical Research. Journal of Rheumatic Diseases, 26(1), 511. https://doi.org/10.4078/jrd.2019.26.1.5.

Laurens, T., Batlolona, F. A., Batlolona, J. R., \& Leasa, M. (2018). How Does Realistic Mathematics Education ( RME ) Improve Students ' Mathematics Cognitive Achievement? EURASIA Journal of Mathematics, Science and Technology Education, 14(2), 569-578. https://doi.org/10.12973/ejmste/76959.

Leow, F. T., \& Neo, M. (2014). Interactive multimedia learning: Innovating classroom education in a Malaysian university. Turkish Online Journal of Educational Technology, 13(2), 99-110.

Lewis, S., \& Holloway, J. (2019). Datafying the teaching 'profession': remaking the professional teacher in the image of data. Cambridge Journal of Education, 49(1), 35-51. https://doi.org/10.1080/0305764X.2018.1441373.

Lilliefors, H. W. (2017). On the Kolmogorov-Smirnov Test for Normality with Mean and Variance Unknown. Journal of the American Statistical Association, 62(318), 399-402. https://doi.org/10.2307/2283970.

Lopez-Belmonte, J., Marin-Marin, J. A., Soler-Costa, R., \& Moreno-Guerrero, A. J. (2020). Arduino Advances in Web of Science. A Scientific Mapping of Literary Production. IEEE Access, 8, 128674-128682. https://doi.org/10.1109/ACCESS.2020.3008572.

Maharani, Maupa, H., \& Aswan, A. (2020). Knowledge Management And Entrepreneurship Aspects Of Performance Through Competitive Advantage Of Smes In Makassar. Hasanuddin Journal of Applied Business and Entrepreneurship, 3(1), 9. https://doi.org/10.18415/ijmmu.v7i7.1861.

Malterud, K., Siersma, V. D., \& Guassora, A. D. (2015). Sample Size in Qualitative Interview Studies : Guided by Information Power. Qualitative Health Research For, 1-8. https://doi.org/10.1177/1049732315617444.

Manurung, S. R., \& Panggabean, D. D. (2020). Improving students' thinking ability in physics using interactive multimedia based problem solving. Cakrawala Pendidikan. https://doi.org/10.21831/cp.v39i2.28205.

Mazidah, Erna, M., \& Anwar, L. (2020). Developing an Interactive Chemistry E-Module for Salt Hydrolysis Material to Face the Covid-19 Pandemic Developing an Interactive Chemistry E-Module for Salt Hydrolysis Material to Face the Covid-19 Pandemic. Journal of Physics: Conference Series, 1-6. https://doi.org/10.1088/1742-6596/1655/1/012051.

Mohajan, H. K. (2018). Qualitative Research Methodology in Social Sciences and Related Subjects Qualitative Research Methodology in Social Sciences and Related Subjects. Journal of Economic Development, Environment and People, 7(1), 23-48. https://doi.org/10.26458/jedep.v7i1.571.

Mortara, M., Catalano, C. E., Bellotti, F., Fiucci, G., Mortara, M., Catalano, C. E., Bellotti, F., Fiucci, G., \& Hourypanchetti, M. (2015). Learning cultural heritage by serious games. Journal of Cultural Heritage, 15(3), 10. https://doi.org/10.1016/j.culher.2013.04.004.

Mulyadi, R, S., Atmazaki, \& Agustina. (2020). The Development Of E-Modules Based on Adobe Flash For Indonesian Subjects At IAIN Bukittinggi. Journal of Physics Conference Series, 1471, 1-9. https://doi.org/10.1088/1742-6596/1471/1/012002.

Nasution, F. H. (2017). Implementasi Pembelajaran Problem Solving Untuk Meningkatkan Kemampuan Pemecahan Masalah Fisika Matematika Mahasiswa. Jurnal Education And Development STKIP Tapanuli Selatan, 7(5), 10-13.

Nasution, L. M. (2017). Statistik Deskriptif. Jurnal Hikmah, 14(21), 49-55. https://doi.org/10.1021/ja01626a006.

Nisa, W. L., Ismet, I., \& Andriani, N. (2020). Development of E-Modules Based on Multi-representations in 
Solid-State Physics Introductory Subject. Berkala Ilmiah Pendidikan Fisika, 8(2), 73. https://doi.org/10.20527/bipf.v8i1.7690.

Nurvianti, I., \& Syarkowi, A. (2018). Penggunaan Komik pada Pembelajaran Fluida Statis di Kelas XI IPA SMA Negeri 2 Kota Jambi Tahun 2017. Jurnal Penelitian Pembelajaran Fisika, 9(1), 59-65. https://doi.org/10.26877/jp2f.v9i1.2124.

Ogungbamila, B., \& Bola Udegbe, I. (2014). Gender differences in the effects of perception of organizational injustice on workplace reactivity. Europe's Journal of Psychology, 10(1), 150-167. https://doi.org/10.5964/ejop.v10i1.575.

Owusu-Fordjour, C., Koomson, C. K., \& Hanson, D. (2020). The Impact of Covid-19 on Learning-The Perspective of the Ghanaian Student. European Journal of Education Studies, 7(3), 88-101. https://doi.org/10.5281/zenodo.3753586.

Pal, S. K., Singh, H. P., Kumar, S., \& Chatterjee, K. (2018). A family of efficient estimators of the finite population mean in simple random sampling. Journal of Statistical Computation and Simulation, 88(5), 920-934. https://doi.org/10.1080/00949655.2017.1408808.

Pathoni, H., Jufrida, Saputri, I., \& Sari, W. (2017). Persepsi Mahasiswa Terhadap E-modul Pembelajaran Mata Kuliah Fisika Atom dan Inti. Jurnal Eksakta Pendidikan (JEP), 1(1), 55-62. https://doi.org/10.24036/jep/vol1-iss1/35.

Perry, D. G., Pauletti, R. E., \& Cooper, P. J. (2019). Gender identity in childhood: A review of the literature. International Journal of Behavioral Development, 43(4), 289-304. https://doi.org/10.1177/0165025418811129.

Putri, I. T., Aminoto, T., \& Pujaningsih, F. B. (2020). Pengembangan e-modul fisika berbasis pendekatan saintifik pada materi teori kinetik gas. Edufisika: Jurnal Pendidikan Fisika, 5(1), 1-11. https://doi.org/10.15548/nsc.v5i1.894.

Qiong, 0. (2017). A Brief Introduction to Perception. Studies in Literature and Language, 15(4), 18-28. https://doi.org/10.3968/10055.

Queiros, A., Faria, D., \& Almeida, F. (2017). Strenght and Limitations of Qualitative and Quantitative Research Methods. European Journal of Education Studies, 3(9), 369-387. https://doi.org/10.5281/zenodo.887089.

Rahayu, I., \& Sukardi. (2020). The Development Of E-Modules Project Based Learning for Students of Computer and Basic Networks at Vocational. Journal Of Education Technology, 4(4), 398-403. https://doi.org/10.23887/jet.v4i4.29230.

Ramadhan, M. A., Handoyo, S. S., \& Alfarisi, M. M. (2020). Pengembangan Bahan Ajar Mekanika Tanah Berbasis E-Modul Pada Program Studi Pendidikan Teknik Bangunan, Universitas Negeri Jakarta. Jurnal Pendidikan Teknik Sipil (JPenSil), 9(1), 1-7. https://doi.org/10.21009/jpensil.v9i1.11987.

Rizkiyah, E., Susanto, N., \& Nugroho, S. (2016). Perbedaan Persepsi Risiko Ditinjau Dari Gender Pada Kegiatan Pendakian Gunung. Industrial Engineering Online Journal, 5(4).

Rohaeti, E. E., Ramadan, B. G., \& Fitriani, N. (2019). Cognitive Stage Relation with Creative Thinking Ability and Mathematical Learning Interests. Journal of Physics: Conference Series, 1315(1). https://doi.org/10.1088/1742-6596/1315/1/012079.

Rosidah, Ketut Budayasa, I., \& Juniati, D. (2018). An Analysis of Statistical Reasoning Process of High School Students in Solving the Statistical Problem. Journal of Physics: Conference Series, 1028(1). https://doi.org/10.1088/1742-6596/1028/1/012125.

Samuelsson, M., \& Samuelsson, J. (2016). Open Review of Educational Research Gender differences in boys ' and girls ' perception of teaching and learning mathematics. Open Review of Educational Research, 3(1), 18-34. https://doi.org/10.1080/23265507.2015.1127770.

Saputri, D. F., Fadilah, S., \& Wahyudi, W. (2016). Efektivitas Penggunaan Buku Ajar Fisika Matematika Berbasis Inkuiri dalam Perkuliahan Fisika Matematika. Jurnal Penelitian \& Pengembangan Pendidikan Fisika, 02(2), 7-14. https://doi.org/10.21009/1.02202.

Serbin, K. S., Robayo, B. J. S., Truman, J. V., Watson, K. L., \& Wawro, M. (2020). Characterizing quantum physics students' conceptual and procedural knowledge of the characteristic equation. The Journal of Mathematical Behavior, 58. https://doi.org/10.1016/j.jmathb.2020.100777.

Serdyukov, P. (2017). Innovation in education: what works, what doesn't, and what to do about it? Journal of Research in Innovative Teaching \& Learning, 10(1), 4-33. https://doi.org/10.1108/jrit-10-20160007.

Serevina, V., Sunaryo, Raihanati, Astra, I. M., \& Sari, I. J. (2018). Development of E-Module Based on Problem Based Learning ( PBL ) on Heat and Temperature to Improve Student 's Science Process Skill. The Turkish Online Journal of Education Technology, 17(3), 26-36.

Seruni, R., Munawaoh, S., Kurniadewi, F., \& Nurjayadi, M. (2019). Pengembangan Modul Elektronik (EModule) Biokimia Pada Materi Metabolisme Lipid Menggunakan Flip Pdf Professional. JTK (Jurnal 
Tadris Kimiya), 4(1), 48-56. https://doi.org/10.15575/jtk.v4i1.4672.

Sharma, G. (2017). Pros and cons of different sampling techniques. International Journal of Applied Research, 3(7), 749-752.

Shishigu, A., Hailu, A., \& Anibo, Z. (2018). Problem-based learning and conceptual understanding of college female students in physics. Eurasia Journal of Mathematics, Science and Technology Education, 14(1), 145-154. https://doi.org/10.12973/ejmste/78035.

Sickle, J. Van. (2016). Discrepancies between student perception and achievement of learning outcomes in a flipped classroom. Journal of the Scholarship of Teaching and Learning, 16(2), 29-38.

Sitorus, D. S., Siswandari, \& Kristiani. (2019). Character Value To Improve Students ' Learning Outcomes And. Cakrawala Pendidikan, 38(1), 120-129. https://doi.org/10.21831/cp.v38i1.20878.

Sofyan, H., Anggrereini, E., \& Saasiah, J. (2019). Development of E-Modules Based on Local Wisdom in Central Learning. European Journal of Education Research, 8(4), 1137-1143. https://doi.org/10.12973/eu-jer.8.4.1137.

Solikin, I. (2018). Implementasi E-Modul pada Program Studi Manajemen Informatika Universitas Bina Darma Berbasis Web Mobile. Jurnal RESTI (Rekayasa Sistem Dan Teknologi Informasi), 2(2), 492497. https://doi.org/10.29207/resti.v2i2.393.

Soto, C. J., \& John, O. P. (2017). The Next Big Five Inventory ( BFI-2 ): Developing and Assessing a Hierarchical Model With 15 Facets to Enhance Bandwidth , Fidelity , and Predictive Power. Journal of Personality and Social Psychology, 113(1), 117-143. https://doi.org/10.1037/pspp0000096.

Sriwahyuni, I., Risdianto, E., \& Johan, H. (2019). Pengembangan Bahan Ajar Elektronik Menggunakan Flip Pdf Professional Pada Materi Alat-Alat Optik Di Sma. Jurnal Kumparan Fisika, 2(3), 145-152. https://doi.org/10.33369/jkf.2.3.145-152.

Sugiyanto, S., Wena, M., \& Isnandar, I. (2019). Developing Learning Materials Based On Training Within Industry (Twi) To Improve The Building Construction Student's Learning Outcomes. Jurnal Ilmu Pendidikan, 24(2). https://doi.org/10.17977/um048v24i2p80-85.

Sullivan, A. (2020). Sex and the census: why surveys should not conflate sex and gender identity. International Journal of Social Research Methodology, 23(5), 517-524. https: //doi.org/10.1080/13645579.2020.1768346.

Suprianto, A., Ahmadi, F., \& Suminar, T. (2019). The Development of Mathematics Mobile Learning Media to Improve Students' Autonomous and Learning Outcomes. Journal of Primary Education, 8(1), 84-91. https://doi.org/10.2991/assehr.k.200827.115.

Suzuki, S. N., Akimoto, Y., Suzuki, K., Okada, A., Hirata, K., Kato, T., Yajima, K., Kanematsu, H., Fukumoto, T., \& Yoshikawa, F. (2020). Development of A-txt system compatible introductory teaching materials for Electric Power Engineering using gaming simulation. Procedia Computer Science, 176, 1557-1566. https://doi.org/10.1016/j.procs.2020.09.167.

Tanjung, Y. I. (2018). Pengaruh Model Pembelajaran Berbasis Masalah Teknik Polya terhadap Hasil Belajar dan Aktivitas Mahasiswa pada Mata Kuliah Fisika Matematika II. Jurnal Ikatan Alumni Fisika Universitas Negeri Medan, 4(2), 1-26. https://doi.org/10.24114/jiaf.v4i2.10808.

Tekedere, H., \& Göker, H. (2016). Examining the Effectiveness of Augmented Reality Applications in Education : A Meta-Analysis. International Journal of Environmental \& Science Education, 11(16), 9469-9481. https://doi.org/10.24114/jiaf.v4i2.10808.

Todd, S. (2014). Between Body and Spirit: The Liminality of Pedagogical Relationships. Journal of Phylosophy of Education, 48(2), 56-72. https://doi.org/10.1002/9781118944707.ch4.

Ünal, F., Tarhan, S., \& Köksal, E. Ç. (2018). Gender and Perception of Profession. Journal of Education and Training Studies, 6(3a), 35. https://doi.org/10.11114/jets.v6i3a.3156.

Willits, F. K., Theodori, G. L., \& Luloff, A. E. (2016). Another Look at Likert Scales. Journal of Rural Social Sciences, 31(3), 126-139. https://doi.org/10.1017/S0036930615000770.

Winatha, K. R., Suharsono, N., \& Agustin, K. (2018). Pengembangan E-Modul Interaktif Berbasis Proyek Mata Pelajaran Simulasi Digital. Jurnal Pendidikan Teknologi Dan Kejuruan, 15(2), 188-199. https://doi.org/10.23887/jtpi.v8i1.2238.

Woerkom, M. Van, Mostert, K., Els, C., Bakker, A. B., Beer, D., \& Jr, S. R. (2016). Strengths use and deficit correction in organizations : development and validation of a questionnaire. European Journal of Work and $\quad$ Organizational 960-975. https: //doi.org/10.1080/1359432X.2016.1193010.

Wu, H., \& Leung, S. O. (2017). Can Likert Scales be Treated as Interval Scales?-A Simulation Study. Journal of Social Service Research, 43(4), 527-532. https:/ /doi.org/10.1080/01488376.2017.1329775.

Yunita, W., \& Maisarah, I. (2020). Students ' Perception On Learning Language At The Graduate Program OF English Education Amids The Covid 19 Pandemic. Linguists: Journal of Linguistics and Language Teaching, 2069(6), 107-120. https://doi.org/10.29300/ling.v6i2.3718. 